\title{
Pengaruh Kompensasi Terhadap Kinerja Pegawai Pada Dinas Perindustrian dan Perdagangan Provinsi Jambi
}

\author{
Khuluqon Azima \\ Fakultas Ekonomi Universitas Batanghari Jambi \\ *Correspondence email : khuluqon.azima@unbari.ac.id
}

\begin{abstract}
The purpose of this study was to determine whether there is an effect of compensation on the performance of employee. Primary data sources using questionnaires taken directly on the object of research, namely the Department of Industry and Trade of Jambi Province with a population of 130 respondents. This research uses quantitative descriptive analysis and the data is processed using SPSS 24, namely by simple linear regression analysis. The results showed that the regression equation was $Y=1.416+0.607 X+e$. Then the value of the coefficient of determination (R2) is 0.297 which means that the compensation variable $(X)$ is able to explain the performance variable $(Y)$ at the Department of Industry and Trade of Jambi Province by $29.7 \%$ while $70.3 \%$ is influenced by other variables outside the variables studied. . And partially the magnitude of the effect of the compensation variable is 7.362 and ttable is 1.979. from the comparison results, it can be seen that tcount is greater than ttable (tcount > ttable). With that Ho is rejected and Ha is accepted. By comparing the number of significant levels (sig) research with a significant level of 0.05 then $0.000<0.05$, so it can be said that there is a significant influence between compensation on the performance of the Department of Industry and Trade of Jambi Province.
\end{abstract}

Keywords: performance, compensation

\section{Pendahuluan}

Manajemen Sumber.Daya.Manusia (MSDM) adalah salah satu cara dalam peningkatan Sumber Daya Manusia. Hal ini dikarenakan manajemen merupakan suatu kegiatan yang mengarahkan seseorang maupun sumbersumber lainnya dalam mencapai tujuan yang sudah direncanakan sebelumnya. Kualitas Sumber Daya Manusia punya peranan yang amat penting dalam mempengaruhi jalannya organisasi karena merupakan motor penggerak organisasi agar diperoleh organisasi yang efektif dan efisien. Diambil dari literatur manejemen didapat beramacam konsep tentang kinerja (performance). Pada umumnya, pendefinisian kinerja itu sendiri mengacu pada suatu hasil (prestasi atau penampilan) kerja yang dicapai oleh seseorang atau suatu kelompok dalam suatu organisasi (perusahaan) berdasarkan satuan waktu atau ukuran tertentu. Pemahaman seperti ini mengandung pengertian yang luas, terutama dari segi pendekatan dan ruang lingkup kajiannya serta penggunaan kriteria atau indikator untuk menentukan prestasi atau penampilan kerja. Pengertian kinerja yang mengacu pada pencapaian hasil (prestasi atau penampilan) kerja, dari segi pendekatan dan ruang lingkup kajiannya dimungkinkan dapat dilakukan dari aspek individual atau organisasial.

Sisi individual seperti yang dikemukakan, bahwasanya kinerja adalah hasil kerja orang pada satu satuan waktu atau ukuran tertentu. Kinerja adalah penampilan dari suatu hasil kerja, baik itu kuantitas maupun kualitas dalam suatu organisasi. Penampilan hasil kerja tersebut tidak terbatas pada individu yang memangku jabatan fungsional maupun structural saja, melainkan juga pada keseluruhan kerja atau kegiatan yang dikerjakan oleh orang dalam organisasi. Kemudian pada aspek organisasional, kinerja lebih diartikan sebagai hasil kerja yang dicapai oleh suatu organisasi (perusahaan). Lingkup kajian kinerja tidak lagi melihat peran individu tetapi lebih fokus kepada hasill kerja yang terkait dengan pencapaian tujuan organisasi, baik itu berdasarkan kelompok fungsional perusahaan maupun hasil kerja yang dicapai oleh unit-unit kerja yang ada. Selanjutnya hal yang dapat mempengaruhi kinerja suatu organisasi adalah dengan adanya pemberian suatu kompensasi dari organisasi tersebut kepada para pegawainya. Perlu diketahui bahwasanya kompensasi itu perlu dibedakan dengan pemberian gaji dan pemberian upah, dikarenanakan gaji dan upah merupakan salah satu bentuk nyata atas pemberian kompensasi. Bentuk kompensasi bukan hanya berupa upah dan gaji, tetapi ada banyak contohnya seperti tunjangan dan sebagainya. Menurut Sedarmayanti (2014) kompensasi itu adalah sesuatu yang didapat oleh karyawan sebagai balas jasa atas kerja mereka.

Adapun kompensasi yang diterima Pegawai Dinas Perindustrian dan Perdagangan Provinsi Jambi adalah sebagai berikut, Gaji (Disesuaikan dengan pangkat/golongan/masa kerja) dengan mengikuti peraturan Departemen KetenagaKerjaan) dan Tambahan Tunjangan Pegawai (TPP). Pemerintahan Provinsi Jambi membayarkan Tambahan Tunjangan Pegawai (TPP), menggunakan sistem gaji tunggal atau dikenal dengan sebutan single salary system bagi Aparatur Sipil Negara (ASN). Tambahan Tunjangan Pegawai (TPP) dibayarkan berdasarkan kedisiplinan pegawai serta berdasarkan pencapaian kinerja harian, hal ini dibuktikan dalam laporan kinerja oleh masing-masing Organisasi Perangkat Daerah (OPD).

\section{Tinjauan Pustaka}


Kompensasi tidak terlalu tergantung pada kesepahaman antara organisasi dan perwakilan, dalam urusan tertentu otoritas publik bekerja sebagai pembuat pengaturan atau pedoman di bidang bisnis. Artinya dalam penerapan kompensasi ada dua kepentingan yang harus diperhatikan, yaitu kepentingan perkumpulan dan kepentingan pekerja. Kompensasi harus berbeda dari gaji dan upah, mengingat kompensasi tidak sama dengan gagasan gaji dan upah. Tingkat gaji dan upah adalah salah satu jenis kompensasi asli. Jenis kompensasi itu sendiri ada banyak model seperti contohnya tunjangan dan sebagainya.Menurut Hasibuan (2012) kompensasi merupakan semua pembayaran sebagai uang tunai, produk yang diterima langsung atau dengan penerimaan yang diterima oleh pekerja sebagai trade-off untuk balas jasa yang diberikan kepada organisasi. Sementara itu, seperti yang ditunjukkan Rivai (2011) menjelaskan bahwa sesuatu yang diperoleh sebagai pengganti komitmen terhadap organisasi. Dengan cara ini, kompensasi memiliki kepentingan yang sangat besar, serta terdiri dari tingkat gaji dan upah, dan dapat berbentuk pula tunjangantunjangan, fasilitas dan masih lain-lain yang dapat dihargai secara tunai dan biasanya akan diperoleh oleh perwakilan yang konsisten untuk menjaga dengan sifat pekerjaan. Selain itu, juga dapat diartikan sebagai alat untuk membangkitkan semangat yang tinggi pada karyawan.

Kinerja adalah gambaran derajat ketercapaian pelaksanaan suatu tindakan pengaturan dalam memahami tujuan, sasaran, misi, visi dan kebijakan suatu organisasi. Suatu kinerja yang baik atau tidak baik diprediksi jika tujuan ideal dapat dicapai dengan tepat seperti yang ditunjukkan sesuai target atau harapan. Kinerja diidentikkan dengan pekerjaan yang telah diselesaikan. Pencapaian hasil kinerja yang ideal yaitu dengan dapat mencapai atau menciptakan tujuan dari perusahaan tersebut. Adapun Menurut Mangkunegara (2011), kinerja adalah konsekuensi dari pekerjaan dalam kualitas dan jumlah yang dicapai oleh seorang karyawan dalam melakukan kewajibannya sesuai dengan kewajiban yang diberikan kepadanya. Sedangkan menurut Hasibuan (2014) kinerja adalah suatu hasil pekerjaan yang diperoleh oleh seseorang dalam melakukan pengalaman, kesungguhan dan waktu. Tugas yang diturunkan tergantung pada kemampuan. Mengingat sebagian pemahaman dari para ahli yang tersebut, dapat diduga bahwa kinerja adalah hasil akhir dari pekerjaan yang dilakukan oleh perwakilan atau pekerja sesuai dengan kewajibannya tergantung pada kemampuan dan penguasaannya, demikian juga dengan seorang pekerja. semangat untuk mencapai tujuan perkumpulan yang relevan secara sah, tidak menyalahgunakan hukum dan sesuai dengan etika dan moral.

Adapun yang menjadi indikator pada variabel kompensasi menurut Rivai (2011) sebagai berikut: (1) Gaji; (2) Insentif; (3) Bonus; (4) Asuransi kesehatan; (5) Tunjangan transport; (6) Tunjangan pensiun; dan (7) Tunjangan hari raya. Sedangkan menurut Mangkunegara (2011) yang menjadi indikator dalam variabel kinerja adalah sebagai berikut: (1) Kualitas kerja; (2) Kuantitas kerja; (3) Tanggung Jawab; (4) Kerjasama; (5) Inisitif. Memang kompensasi itu bukanlah satu-satunya faktor yang mempengaruhi kinerja karyawan, akan tetapi kompensasi tetap diakui sebagai salah satu faktor penentu dalam rangka peningkatan kinerja karywan. Jika dihubungkan dengan hasil evaluasi pekerjaan, maka karyawan akan lebih semangat dan memaksimalkan pekerjaannya, dikarenakan mereka merasa dihargai karyanya. Para karyawan menginginkan bahwa kinerja akan berhubungan positif dengan kompensasi yang diberikan oleh perusahaan.

\section{Metode}

Objek penelitian dalam penelitian ini adalah seluruh pegawai negeri sipil (PNS) Dinas Perindustrian dan Perdagangan Provinsi Jambi yang berjumlah 130 (seratus tiga puluh) orang. Sumber data yang diperoleh dalam penelitian ini berasal dari kuesioner responden secara langsung pada pegawai Dinas Perindustrian dan Perdagangan Provinsi Jambi. Pada penelitian ini menggunakan metode sampel dengan pendekatan penelitian kuantitatif dan kualitatif dengan menggunakan suatu perangkat kuesioner terstruktur yang ditujukan kepada para responden. Analisis regeresi linier sederhana adalah suatu alat analisis yang digunakan untuk mengukur pengaruh antar variabel bebas $(\mathrm{X})$ dan variabel terikat (Y) (Sugiyono, 2010). Model persamaan untuk menghitung regresu linier sederhana yaitu : $\mathrm{Y}=\mathrm{a}$ $+\mathrm{bX}+\mathrm{e}$

$\mathrm{Y}=$ Kinerja; $\mathrm{a}=$ Nilai Konstanta; $\mathrm{b}=$ Koefisien Variabel Independen; $\mathrm{X}=$ Insentif; $\mathrm{e}=$ Error

Menggunakan uji koefisien korelasi untuk mengukur seberapa jauh kemampuan model dalam menjelaskan variasi dari variabel terikat. Nilai koefisien determinasi $\left(\mathrm{R}^{2}\right)$ berada pada rentang skala nol (0) dan satu (1). Jika nilai koefisien determinasi yang mendekati angka nol (0) berarti kemampuan model dalam menerangkan variabel terikat sangat terbatas. Sebaliknya dilihat apabila nilai koefisien determinasi variabel mendekati satu (1) itu artinya kemampuan variabel bebas dalam menimbulkan keberadaan variabel terikat akan semakin kuat. Uji t digunakan untuk menguji signifikansi hubungan antara variabel $\mathrm{X}$ dan $\mathrm{Y}$, apakah variabel $\mathrm{X}$ (Kompensasi) berpengaruh terhadap variabel Y (Kinerja) secara terpisah atau parsial, menurut Priyanto (2013). Hipotesis yang digunakan dalam pengujian ini adalah

a. Merumuskan hipotesis

Ho:Diduga kompensasi tidak berpegaruh signifikan terhadap kinerja pegawai pada Dinas Perindustrian dan Perdagangan Provinsi Jambi. 
Ha : Diduga kompensasi berpengaruh signifikan terhadap kinerja pegawai pada Dinas Perindustrian dan Perdagangan Provinsi Jambi.

b. Menentukan ttabel dengan menggunakan tingkat keyakinan 95\%, $\alpha=5 \%$, df 1 (jumlah variabel -1), df 2 (n-k-1), ( $\mathrm{n}$ adalah jumlah kasus dan $\mathrm{k}$ adalah jumlah variabel independen). $\mathrm{t}$ hitung $=$ koefisien regresi/standar deviasi.

1) Bila t-tabel< t-hitung, dan thitung 435 ariable independen secara individual tidak berpengaruh terhadap variable dependen.

2) Bila t-hitung > t-tabel, dan thitung variabel independen secara individu berpengaruh terhadap variabel dependen.

3) Menentukan variabel independen mana yang mempunyai pengaruh paling dominan terhadap variabel dependen, hubungan ini dapat dilihat dari koefisien regresinya.

\section{Hasil}

Tabel 1

Hasil Uji Regresi Linier Sederhana

\begin{tabular}{c|r|r|r|c|c}
\hline Model & Unstandardized B & Coefficients Std. Error & Standardized Coefficients Beta & t & Sig. \\
\hline (Constant) & 1.416 & .263 & & 5.390 & .000 \\
\hline Kompensasi & .607 & .083 & .545 & 7.362 & .000 \\
\hline
\end{tabular}

Sumber : olahan data

Berdasarkan Tabel 1 hasil uji regresi linier sederhana didapat hasil dari koefisien untuk variabel bebas $\mathrm{X}=$ 0.607 , nilai konstanta sebesar 1.416 , sehingga model persamaan regresi yang diperoleh :

$\mathrm{Y}=1.416+0.607 \mathrm{X}+\mathrm{e}$

Nilai konstanta sebesar 1.416 artinya apabila variabel independen (Kompensasi) bernilai nol (0), maka variabel dependen ( kinerja ) yaitu akan bernilai 1.416. Koefisien regresi variabel kompensasi bernilai positif sebesar 0.607 artinya apabila variabel X mengalami peningkatan sebesar 1 (satu), maka variabel Y akan mengalami peningkatan sebesar 0.607 .

Tabel 2

Hasil Koefisisen Determinasi $\left(\mathbf{R}^{2}\right)$

\begin{tabular}{|l|r|r|r|r|}
\hline \multicolumn{1}{|c|}{ Model } & R & \multicolumn{1}{c|}{ R Square } & Adjusted R Square & \multicolumn{1}{c|}{ Std. Error of the Estimate } \\
\hline 1 & .545 & .297 & .292 & .39818 \\
\hline
\end{tabular}

Sumber : Olahan data

Tabel 2, nilai koefisien determinasi (R2) sebesar 0.297 yang artinya menyatakan bahwa variabel kompensasi (X) mampu menjelaskan variabel kinerja (Y) pada Dinas Perindustrian dan Perdagangan Provinsi Jambi sebesar 29,7\% sedangkan 70,3\% dipengaruhi oleh variabel lainnya diluar variabel yang diteliti. Berdasarkan pada Tabel 1, dengan melihat hasil t-hitung dapat diketahui bahwa secara parsial besarnya pengaruh variabel kompensasi sebesar 7.362 dan t-tabel sebesar 1.979, dilihat pada hasil perbandingan maka dapat diketahui t-hitung itu lebih besar dari ttabel (t-hitung > t-tabel). Dengan demikian Ho ditolak dan Ha diterima. Dengan membandingkan besarnya angka taraf signifikan (sig) penelitian dengan taraf signifikan sebesar 0,05 maka $0.000<0,05$; sehingga dapat dikatakan bahwa ada pengaruh signifikan antara kompensasi terhadap kinerja pegawai Dinas Perindustrian dan Perdagangan Provinsi Jambi. Secara parsial terdapat pengaruh kompensasi terhadap kinerja pegawai Dinas Perindustrian dan Perdagangan Provinsi Jambi. Hal ini ditunjukkan dengan nilai t-hitung sebesar 7.362 dan t-tabel sebesar 1.979 dari hasil perbandingan maka dapat diketahui t-hitung lebih besar dari t-tabel (t-hitung > t-tabel). Dengan itu Ho ditolak dan Ha diterima. Dengan membandingkan besarnya angka taraf signifikan (sig) penelitian dengan taraf signifikan sebesar 0,05 maka $0.000<0,05$; sehingga dapat dkatakan bahwa ada pengaruh signifikan antara kompensasi terhadap kinerja pegawai Dinas Perindustrian dan Perdagangan Provinsi Jambi.

\section{Simpulan}

Berdasarkan hasil penelitian bahwa secara parsial terdapat pengaruh kompensasi terhadap kinerja pegawai Dinas Perindustrian dan Perdagangan Provinsi Jambi. Hal ini ditunjukkan dengan membandingkan besarnya angka taraf signifikan (sig) penelitian dengan taraf signifikan sebesar 0,05 maka $0.000<0,05$, sehingga dapat dkatakan bahwa ada pengaruh signifikan antara kompensasi terhadap kinerja pegawai Dinas Perindustrian dan Perdagangan Provinsi Jambi. 
Khuluqon Azima, Pengaruh Kompensasi Terhadap Kinerja Pegawai Pada Dinas Perindustrian dan Perdagangan Provinsi Jambi

\section{Daftar Pustaka}

Anwar Prabu Mangkunegara. 2011. Manajemen Sumber Daya ManusiaPerusahaan. Remaja Rosdakarya. Bandung. Hasibuan. S.P. 2012. Manajemen Sumber Daya Manusia. Edisi Revisi. Jakarta: PT. Bumi Aksara.

Hasibuan, Malayu.S.P. 2014. Manajemen Sumber Daya Manusia. Edisi Revisi, Cetakan Kelima. Jakarta: PT. Bumi Aksara.

Priyanto. 2013. Data Statistik. Cetakan Pertama. Yogyakarta: Mediakom.

Rivai. Veithzal. 2011. Manajemen Sumber Dayauntuk Perusahaan. Jakarta: Raja Grafindo Persada.

Sedarmayanti. 2014. Sumber Daya Manusia dan Produktivitas Kerja. Jakarta: Mandar Maju.

Sugiyono. 2010. Statistik Untuk Penelitian, Bandung: Al Fabeta 